\title{
The Reception of Geoffrey of Monmouth's Work in Italy
}

\author{
Fabrizio De Falco
}

The reception of Geoffrey of Monmouth's work in medieval Italy is an integral part of two fascinating veins of inquiry: the early appearance of the Matter of Britain in Italy and its evolution in various social, political, and cultural contexts around the Peninsula. ${ }^{1}$ At the beginning of the 12th century, before the De gestis Britonum was written, an unedited Arthurian legend was carved on Modena Cathedral's Portale della Pescheria, a stop for pilgrims headed to Rome along the Via Francigena. ${ }^{2}$ Remaining in the vicinity of Modena, the only continental witness of the First Variant Version of the $D G B$ (Paris, Bibliothèque de l'Arsenal, 982) can be connected to Nonantola Abbey. ${ }^{3}$ Moving to the kingdom of Sicily, in 1165 the archbishop of Otranto commissioned an enormous mosaic for the cathedral, and Arthur is depicted in one of the various scenes, astride a goat, fighting a large cat. ${ }^{4}$ To describe Geoffrey of Monmouth's reception in

1 E.G. Gardener, The Arthurian Legend in Italian Literature, London and New York, 1930; D. Delcorno Branca, "Le storie arturiane in Italia", in P. Boitani, M. Malatesta, and A. Vàrvaro (eds.), Lo spazio letterario del Medioevo, II. Il Medioevo volgare, III: La ricezione del testo, Rome, 2003, pp. 385-403; G. Allaire and G. Paski (eds.), The Arthur of the Italians: The Arthurian Legend in Medieval Italian Literature and Culture (Arthurian Literature in the Middle Ages, 7), Cardiff, 2014.

2 In this version, Gawain is the protagonist and Arthur is not yet king. R. Lejeune and J. Stennon, "La legende arthurienne dans la sculpture de la cathedrale de Modène", Cahiers de Civilisation Medievale 6 (1963), 281-96; L.M. Gowan, "The Modena Archivolt and the Lost Arthurian Tradition", in W. Van Hoecke, G. Tournoy, and W. Webecke (eds.), Arturus Rex, Vol. II. Acta Conventus Lonvaliensis 1987, Leuven, 1991, pp. 79-86.

3 D. Delcorno Branca, "Diffusione della materia arturiana in Italia: per un riesame delle 'tradizioni sommerse'", in P. Benozzo (ed.), Culture, livelli di cultura e ambienti nel Medioevo occidentale: atti del IX Convegno della Società italiana di filologia romanza, Bologna 5-8 ottobre 2009, Rome, 2012, pp. 321-40, at p. 323; For Italian manuscripts, see the catalogue in Crick, $D R$, nos. 71, 72, 109, 163, 172, 181, 182.

4 It is the demon Cath Palug from the Welsh tradition. The story of his battle with Arthur appears in French romances from the late 12th and early 13th centuries. Its presence in Otranto illustrates the ties between the Norman Kingdom of Sicily and northern Europe. Cf. C. Settis Frugoni, "Per una lettura del mosaico pavimentale della cattedrale di Otranto", Bullettino dell'Istituto Storico Italiano per il Medio Evo 8o (1968), 213-56; H. Nickel, "About Palug's Cat and the Mosaic of Otranto", Arthurian Interpretations 3:2 (1989), 96-105. 
Italy, one must address two topics: the development of the Italian Arthurian tradition - as well as its polemical and political use - and the diffusion of the $D G B$ along with its fascinating historiography.

In the courtly contexts of the Empire and the Kingdom of Sicily in the 12th and 13 th centuries, we can already see how ephemeral the line was between medieval historiography's interest in the $D G B$ and the use of the Matter of Britain in political battles. The first accurate tradition of Geoffrey of Monmouth's work in Italy was at the Hohenstaufen Imperial Court, when Geoffrey of Viterbo used the $D G B$ in writing his Pantheon (c.1185-90), a universal story in prose and verse intended for the court of the emperor Henry vi. Lucienne Meyer's work on the sources Geoffrey used underlines how the section regarding the history of Britain is a selection of passages from the $D G B$ ending at the prophecy of Arthur's return. ${ }^{5}$ According to Paul Zumthor and Donald Hoffman, Geoffrey of Viterbo initiated the use of Merlin's prophecies in Imperial circles. The prophecies were later used widely in the milieu surrounding Frederick II. ${ }^{6}$ During the same years, in the Kingdom of Sicily's struggle between the Norman nobility and the Empire, the Matter of Britain thoroughly entered the realm of political battle. In 1189, Tancred of Lecce, the natural son of Ruggero II of Altavilla, was crowned king of Sicily by the Norman nobility, in opposition to the rights claimed by Emperor Henry vi by marriage to Costanza d'Altavilla, the heir named by the deceased King William II. While traveling in Sicily in 1191, Richard the Lionheart gave Tancred a sword said to be Excalibur. ${ }^{7}$ In this gift

5 Godfrey of Viterbo, Pantheon, ed. G. Waitz (Monumenta Germaniae Historica, Scriptores, 22), Hanover, 1872, pp. 107-307; L. Meyer, Les légendes des Matières de Rome, de France et de Bretagne dans le "Pantheon" de Godefroi de Viterbe, Paris, 1933, pp. 190-223. The study, however, has various lacunae, cf. F.P. Magoun, Jr., "Les Légendes des matières de Rome, de France et de Bretagne dans le 'Pantheon' de Godefroi de Viterbe by Lucienne Meyer", Speculum 11:1 (1936), 144-46. On Geoffrey of Viterbo as Imperial historian: L.J. Weber, "The Historical Importance of Godfrey of Viterbo", Viator 25:2 (1994), 153-95; K. Hering, "Godfrey of Viterbo: Historical Writing and Imperial Legitimacy at the Early Hohenstaufen Court", in T. Foerster (ed.), Godfrey of Viterbo and His Readers: Imperial Tradition and Universal History in Late Medieval Europe, Farnham, 2015, pp. 47-66.

6 P. Zumthor, Merlin le Prophète, un thème de la littérature polémique, de l'historiographie et des romans, Lausanne, 1943, p. 97; D.L. Hoffman, "Was Merlin a Ghibelline? Arthurian Propaganda at the Court of Frederick II", in M.B. Shichtman and J.P. Carley (eds.), Culture and the King: The Social Implications of the Arthurian Legend, Essays in Honor of Valerie M. Lagorio, Albany, 1994, pp. 113-28. This theme is also addressed in E. Kantorowicz, Federico II Imperatore, Milan, 1976, p. 369 .

7 Benedict of Peterborough, The Deeds of King Henry II, ed. W. Stubbs, Gesta Regis Henrici Secundi Benedicti Abbatis. The Chronicle of the Reigns of Henry II, and Richard I, AD. 1169-1192: Known commonly under the Name of Benedict of Peterborough, 2 vols., London, 1867, vol. 2, p. 169 . 
it is possible to see Richard taking a political position in favor of Tancred and hostile to the Hohenstaufen. ${ }^{8} \mathrm{~A}$ few years later, Otto of Brunswick's Imperial Court saw the birth of the fascinating legend, studied for the first time by Arturo Graf, in which Arthur seeks refuge in Sicily after his final battle. ${ }^{9}$ In the Otia Imperalia ("Entertainment for an Emperor", c.1210), Gervase of Tilbury followed by other authors ${ }^{10}$ - identified Arthur's final refuge as the bowels of Mount Etna, transforming Sicily into Avalon. Gervase of Tilbury was educated at the court of Henry II of England, and Arthur's return - in a work dedicated to Otto IV of Brunswick, grandson of Henry II and enemy of Frederick II - can be seen as a preview of the way in which, later, the Guelf and Ghibelline factions made broad use of the Matter of Britain.

From the 13th to the $15^{\text {th }}$ century, Merlin was the protagonist in a florid tradition independent from Geoffrey of Monmouth, and numerous prophecies attributed to him were written in Italy. ${ }^{11}$ These prophecies referred primarily to Frederick II. The emperor, protagonist of the 13th century prophetic writing, was described, depending on the faction, as the Savior or the Antichrist. ${ }^{12}$ After their initial use in imperial circles, Merlin's prophecies took on increased importance in the Guelf party's polemical output. ${ }^{13}$ The most well-known

8 H. Bresc, "Excalibur en Sicilie", Medievalia 7 (1987), 7-21; M.R. Warren, "Roger of Howden Strikes Back: Investing Arthur of Brittany with the Anglo-Norman Future", Anglo-Norman Studies 21 (1998), 261-72; E. D’Angelo, "Re Artù ed Excalibur dalla Britannia romana alla Sicilia normanna", Atene e Roma 3:4 (2007), 137-58.

9 A. Graf, "Artù nell'Etna", in id. (ed.), Miti, leggende e superstizione nel medioevo, Milan, 1984, pp. 321-38.

10 Gervase of Tilbury, Recreation for an Emperor, ed. and trans. S.E. Banks and J.W. Binns, Otia imperialia. Recreation for an Emperor, Oxford, 2002, pp. 334-37; Cesarius of Heisterbach, Dialogus miraculorum (1219-23); Stephen of Bourbon, Tractatus de diversis materiis predicabilibus (1250-61); Florian et Florete (1250-70); Il detto del gatto lupesco (s. xiii). See A. Pioletti, "Artù, Avalon, l'Etna", Quaderni Medievali 28 (1989), 6-35.

11 Zumthor, Merlin le Prophète; D. Hoffman, "Merlin in Italian Literature", in P. Goodrich and R.H. Thompson (eds.), Merlin: A Casebook, New York, 20o3, pp. 186-96; C. Daniel, Les prophéties de Merlin et la culture politique (XII $-X V I^{e}$ siecles), Turnhout, 2006.

12 Cf. G. Podestà, "Roma nella Profezia (secoli XI-XIII)", in n.n. (ed.), Roma antica nel Medioevo: mito, rappresentazioni, sopravvivenze nella 'Respublica Christiana' dei secoli IX-XIII, atti della quattordicesima Settimana internazionale di studio, Mendola, 24-28 agosto 1998, Milan, 2001, pp. 356-98; F. Delle Donne, Il potere e la sua legittimazione: letteratura encomiastica in onore di Federico II di Svevia, Arce, 2005.

13 Cf. n. 8 of this chapter; P. Ménard, "Les Prophéties de Merlin et l'Italie au XIII" siècle", in K. Busby, B. Guidot, and L.E. Whalen (eds.), "De sens rassis". Essays in Honor of Rupert T. Pickens, Amsterdam and Atlanta, 2005, pp. 431-44; C. Daniel, Les prophéties de Merlin, pp. 341-68. 
cases that present Frederick as the Antichrist are the Verba Merlini $(c .1240)^{14}$ and a prophetic text falsely attributed to Gioacchino da Fiore: Abbot Joachim's Exposition of the Sibyls and Merlin (Expositio abbatis Joachimi super Sibillis et Merlino, c.1240)..$^{15}$ Following this, Merlin's prophecies became an integral part of the internal struggle in various Italian cities between the Guelfs and the Ghibellines. In the boarder district of Treviso, Merlin's prophecies were used to legitimize Ezzelino da Romano's consolidation of power. Ezzelino, the Lord of Padua, was an ally of Frederick II. ${ }^{16}$ Prophéties de Merlin (c.1276), written in French by a certain "Richart d'Irlande", who Lucy Paton identifies as a Venetian Guelf, was one of the most widely disseminated texts. ${ }^{17}$ Involved in the struggle between the Guelfs and the Ghibellines, Merlin was distanced from Geoffrey of Monmouth, becoming part of a rich textual tradition that has not yet been studied in its entirety. ${ }^{18}$

Regarding the dissemination of Geoffrey of Monmouth's work, it is important to address the attention the humanists and their predecessors paid him. His work was known by the Italian intellectual elite and already used as a historic source by Paolino Veneto, who collected passages by Geoffrey of Monmouth and Gervase of Tilbury to write his Compendium (1321-23). ${ }^{19}$ Paolino drew a connection between Geoffrey of Monmouth and Boccaccio, which illustrates the importance given to the $D G B$ in medieval historiography. ${ }^{20}$ Daniela Delcorno Branca's work shows how Boccaccio used the $D G B$ to write the Fall of Princes $\left(c .1355^{-70}\right)^{21}$ and, specifically, the chapter De Arturo

14 The text appears, with some variants, in Salimbene de Adam, Chronicle, ed. O. Holder-Egger, Salimbene de Adam, Chronica fratris Salimbene de Adam ordinis Minorum (Monumenta Germaniae Historica, Scriptores, 32), Hanover, 1905-13, p. 360.

15 O. Holder-Egger, "Italienische Prophetieen des 13. Jahrhunderts. I.", Neues Archiv der Gesellschaft für ältere deutsche Geschichtskunde zur Beförderung einer Gesamtausgabe der Quellenschriften deutscher Geschichten des Mittelalters 15 (1889), 142-78. The Expositio is unedited; for a list of manuscripts, see M. Reeves, The Influence of Prophecy in the Later Middle Ages. A Study in Joachimism, Oxford, 1969, p. 520.

16 Zumthor, Merlin le Prophète, pp. 101-02.

17 Les Prophecies de Merlin, edited from MS. 593 of the Bibliothèque Municipale de Rennes, ed. L.A. Paton, 2 vols. (Modern Language Association of America Monograph Series, 1), New York and London, 1926-27 (repr. New York, 1966), vol. 1, p. 58.

18 For more on the various cities, see C. Daniel, Les prophéties de Merlin, pp. 277-86.

19 Cf. M. Di Cesare, "Problemi di autografia nei testimoni del Compendium e della Satirica Ystoria di Paolino Veneto", Res Publica Litterarum 30 (2007), 39-49.

20 D. Delcorno Branca, Boccaccio e le storie di re Artù, Bologna, 1991, p. 69.

21 Giovanni Boccaccio, On the Fates of Famous Men, ed. P.G. Ricci and V. Zaccaria, Tutte le Opere di Giovanni Boccaccio, gen. ed. V. Branca, 10 vols., Milan, 1967-98, vol. 9; V. Zaccaria, "Le due redazioni del De Casibus", Studi sul Boccaccio 10 (1977-78), 1-26. 
Britonum Rege. ${ }^{22}$ Boccaccio added a number of variants and omitted all fairytale elements. This omission demonstrates his intent to use the $D G B$ as a historiographic instrument, a modus operandi also used in writing his De montibus (begun $c .1355)^{23}$ where Geoffrey of Monmouth served as a reference for his description of British geography. The use of the $D G B$ as a historic source is highlighted in Alessandro Malanca's recent work on Galasso da Correggio's Historia Anglie (c.430). ${ }^{24}$ This work, a reworking of the $D G B$, was dedicated to Count Filippo Maria Anglo Visconti with the encomiastic intent of recalling the legend of the Trojan origins of the Visconti. ${ }^{25}$ The count was a passionate reader of history pertaining to illustrious men, and Galasso da Correggio wished to offer him a synthesis between aristocratic cultural fashion and the humanist ideal. Thus intending to write a Historia as opposed to the fabulae that were in vogue, Galasso drew inspiration from the work of Geoffrey of Monmouth, just as Boccaccio had done before him.

We have seen how, on the one hand, the political use of the Matter of Britain transformed some characters but on the other, the $D G B$ in its original form had a recognized historiographic value. The interaction between these two themes is essential for anyone who wishes to study Geoffrey of Monmouth's reception in medieval Italy. This little-addressed field of study would certainly benefit from further investigation.

\section{Translated from Italian by Lauren Jennings}

22 Giovanni Boccaccio, On the Fates of Famous Men viii.19-20, ed. Ricci and Zaccaria, pp. 729-41; Delcorno Branca, Boccaccio, pp. 69-112.

23 Boccaccio worked on De Montibus for his whole life. Giovanni Boccaccio, De montibus, silvis, fontibus, lacubus, fluminibus, stagnis seu paludibus et de diversis nominibus maris [On mountains, forests, fountains, lakes, rivers, swamps or marshes, and on the many names for the sea], ed. M. Pastore Stocchi, Tutte le Opere di Giovanni Boccaccio, gen. ed. V. Branca, 10 vols., Milan, 1967-98, vol. 8; M. Pastore Stocchi, Tradizione medievale e gusto umanistico nel "De montibus" del Boccaccio, Florence, 1963; Delcorno Branca, Boccaccio, pp. 115-26.

24 The work is contained in the following manuscripts: Paris, Bibliothèque nationale de France, lat. 6o41D; Palermo, Biblioteca Comunale, 2 Qq C 102; and Correggio, Biblioteca Comunale, 33. See A. Malanca, "Le armi e le lettere. Galasso Da Correggio: Autore dell'Historia Anglie", Italia Medioevale e Umanistica 48 (2007), 1-57; id., "Le fonti della materia di Bretagna nell'opera di Galasso da Correggio", Giornale Italiano di Filologia 61 (2009), 271-98.

25 E. Pellegrin, La bibliothèque des Visconti et des Sforza ducs de Milan au XVe siècle, Paris, 1955; M. Zaggia, "Appunti sulla cultura letteraria in volgare a Milano nell'età di Filippo Maria Visconti", Giornale storico della letteratura italiana 170 (1993), 161-219, 321-82. 